\title{
Neda Pintarić, Ivana Čagalj i Ivana Vidović Bolt. (ur.) Komparativnoslavističke lingvokulturalne teme. Srednja Europa, Zagreb, 2019., 409 str.
}

Sredinom 2019. godine tiskan je zbornik Komparativnoslavističke lingvokulturološke teme u Zagrebu u izdavačkoj kući Srednja Europa. Zbornik je plod istoimene međunarodne konferencije i projekta Hrvatske zaklade za znanost [2131] voditeljice Nede Pintarić. Urednice zbornika su Neda Pintarić i Ivana Vidović Bolt, redovite profesorice na Katedri za poljski jezik i knjiženost, te Ivana Čagalj, docentica na Katedri za slovački jezik i književnost. Znanstvena je konferencija održana 9. i 10. veljače 2018. godine u Zagrebu, a uspješno je provedena zahvaljujući organizacijskom odboru koji su činili prof. dr. sc. Ivana Vidović Bolt, doc. dr. sc. Ivana Čagalj i asistent Miroslav Hrdlička. Na konferenciji su 72 izlagača predstavila 55 referata od kojih je nakon recenzentskih postupaka objavljen 41 rad. Zbornik su recenzirali znanstvenici iz triju zemalja Poljske, Slovačke i Hrvatske izv. prof. dr. sc. Lidija Cvikić, doc. PhDr. Márija Dobríková, prof. dr. sc. Patrycjusz Pająk i dr. sc. Dubravka Sesar, prof. emerita. Ukupno je 54 znanstvenika iz Austrije, Bjelorusije, Hrvatske, Poljske, Sjeverne Makedonije, Slovačke, Slovenije i Ukrajine objavilo svoje radove u zborniku, a članci su napisani na hrvatskom, makedonskom, poljskom, slovačkom i engleskom jeziku. Sama tiskovina se sastoji od kazala, Uvodne riječi urednica i samih članaka koji zauzimaju 409 stranica.

Radove, prije svega, objedinjuje poredbeni pristup u širokom smislu, nagovješten već samim naslovom zbornika, konferencije i projekta u okvirima kojega je nastao. Dodirne su točke članaka usporedba i suprotstavljanje pojedinih elemenata jezika i/ili kulture iz različitoga jezikoslovnog, kulturološkog ili glotodidaktičkog pristupa, te predodžba drugoga, često i manjinskoga u međunarodnom kontekstu. Komparativno-kontrastivna analiza odabranih jezičnih pojava najzastupljenija je metoda u člancima; 23 od 41 rad se temelje na usporedbi i suprotstavljanju sastavnica različite jezične građe. Najčešći je jezik koji se s nekim drugim jezikom uspoređuje hrvatski; pojavljuje se kao polazišni jezik u 20 od 23 članaka. U zborniku se najčešće, u 15 radova, uspoređuju pojedini aspekti dvaju jezika, a među njima je najučestaliji poljsko-hrvatski jezični par čije je suprotstavljanje tema 6 članaka. U 7 se članaka tri jezika kompariraju, a u dva se pojavljuje trijada makedonskoga, hrvatskoga i poljskoga jezika. U jednome se članku suprotstavlja više od tri jezika, a među svim uspoređivanim jezicima samo jedan ne pripada slavenskima; to je njemački jezik s kojim se uspoređuju drugi slavenski jezici u dva članka. U Uvodnoj riječi radovi se dijele na dvije skupine, prvoj pripadaju jezikoslovna istraživanja, odnosno članci posvećeni pravopisu, rječotvorju, fleksiji, sintaksi, terminologiji, leksikologiji, frazeologiji, semantici, pragmatici, leksikografiji, dijalektologiji i povijesti slavenskih jezika. Drugu skupinu čine radovi kulturološke i sociolingvističke naravi, usmjereni na međunarodni položaj hrvatskoga jezika i rasprave o njemu, 
analizu jezika u medijima, manjinske jezike i njihov odraz u esejističko putopisnim tekstovima, ali i nekoliko glotodidaktičkih radova.

Aspektu učenja i podučavanja hrvatskoga kao drugoga i stranoga jezika govornika drugih slavenskih jezika posvećeni su članci Ivančice Banković-Mandić Odstupanja u izgovoru naglasaka u slavenskih govornika hrvatskog kao J2 u kojem su analizirane greške govornika iz Poljske, Ukrajine, Slovenije, Rusije, Češke i Bugarske s različitim stupnjem znanja hrvatskoga jezika i uspoređene s greškama govornika talijanskoga jezika, te rad Zrinke Jelaske Srodnost i ini jezici - slavenski kao srodni jezici koji uključuje istraživanje o ovladavanju slavenskih kao stranih jezika nad građom od devedeset jezičnih biografija zagrebačkih studenata kroatistike. Sličnu problematiku kao osnovu istraživanja sadrži članak Katarine Giel Analiza frazeoloških pogrešaka u učenju hrvatskoga kao inog jezika na primjeru studenata iz Poljske koji pokazuje rezultate analize pisanih provjera poljskih studenata, te zaključuje da ju u nastavu stranoga jezika potrebno uključiti više teorijskoga i praktičnoga znanja o frazeologiji, jer upravo to znanje svjedoči o dobroj jezičnoj kompetenciji. Rezultate istraživanja da se među navescima za genitiv, dativ i lokativ jednine pridjeva, zamjenica i brojeva muškoga i srednjega roda najčešće rabe oni za genitiv i to kod studenata diplomskoga studije kroatistike u usporedbi s učenicima srednje škole te studentima hrvatskoga kao stranoga jezika pokazuje rad Sandre Jukići Bojana Prosenjaka Kako govornici slavenskih jezika rabe naveske u hrvatskome jeziku?. Model za podučavanje kulture i njene glavne odrednice u nastavi hrvatskoga kao inoga jezika predlažu Sanda Lucija Udier i Milvia Gulešić Machata u članku Što i kako proučavamo kad poučavamo kulturu.

Položajem i raspravom o hrvatskome jeziku u međunarodnom kontekstu bave se radovi Roberta Bońkowskoga Sytuacja prawna języka chorwackiego jako mniejszościowego w konstytucjach państw byłej Jugosławii (Pravni položaj hrvatskoga jezika kao manjinā u ustavima državā bivše Jugoslavije) u kojem se ističu neravnomjerna prava na korištenje hrvatskoga jezika zajamčena ustavima država bivše Jugoslavije, Jagode Granić Hrvatska »unutarnja« $i$ »vanjska« jezična politika u europskom kontekstu o trenutnom stanju i planiranju statusa jezika kao važnoga dijela nacionalnoga identiteta, te članak Vice Šunjića Polemike o hrvatskom jeziku na stranicama Hrvatske revije u rubrici pisma uredništvu (1975.-1984.) koji daje prikaz rasprava i skrbi hrvatskih emigranata, prije svega kroatista, za normiranje, stvaranje nazivlja, dijalekte i položaj hrvatskoga jezika u SFRJ.

Istraživanju iz područja sociolingvistike posvećen je rad Ima li jezika nakon groba? O pesimizmu, stanju i perspektivama hrvatskoga jezika u Slovačkoj Ivane Čagalj, Anite Skelin Horvat i Aleksandre Ščukanec koji predočuje rezultate kvalitativne analize o upitnoj budućnosti opstanka čakavskih varijeteta hrvatske manjine u Slovačkoj zbog uske upotrebne domene, nedostatka službenoga statusa i pesimizma samih govornika. O sličnome pesimističnom stavu za očuvanje manjinskih jezika iz perspektive pisca, ali ne znanstvenika piše Filip Kozina u članku Budućnost manjinskihjezika iz književnog očišta Karla-Markusa Graußa, gdje razlozi takva stava 
proizlaze iz turističke folklorizacije jezika i međugeneracijske otuđenosti. Odabrani gramatički problem kroz sociolingvističko gledište analizirani su u radu Diane Stolac Sročnost u jeziku Hrvata u Australiji u kojem su pak izdvojeni rezultati pogrešaka u sročnosti pridjeva i imenica, broja i imenice te subjekta i predikata kod druge generacije govornika hrvatskoga jezika dobiveni terenskim istraživanjima.

Analizu jezika u medijima i probleme percepcije drugoga predstavlja rad Danice Ćurković Ili mi ili oni (tragovi novogovora na poljskim i hrvatskim izborima) u kojem se razotkrivaju elementi totalitarnoga diskursa dvadesetoga stoljeća u govorima s predizbornih kampanja poljskih i hrvatskih političara iz 2015. i 2017. godine, kao i članak Slavenske zemlje u talijanskim dnevnim novinama 'La repubblica': analiza sadržaja Magdalene Nigoević i Nikoline Vukančić koji prikazuje reprezentacijske obrasce, razlike među njima i učestalost pojavljivanja slavenskih zemalja koje su članice Europske unije u odabranoj talijanskoj publikaciji.

U članku Željke Čelić Iz čega se pije rakija i vodka u hrvatskome i ruskome jeziku? uspoređuju se narodne tradicije i stereotipi povezani s konzumacijom odabranih alkoholnih pića, kao i morfološka i etimološka analiza naziva pića i kulturnih realija vezanih uz njih. Uspješnu rekonstrukciju jezično-kulturnoga portreta vezanoga uz fizički izgled Poljaka u jezičnoj slici svijeta slovenskih i poljskih ispitanika prokazuje rad Marije Wacławek i Marije Wtorkowske »Nasz wyglad zależy od tego, w jakim lustrze się przejrzymy «-z badań nad stereotypem polaków (»Naš izgled ovisi o tome u kakvom se zrcalu gledamo « - iz istraživanja nad stereotipom Poljaka).

U strogom se smislu dva članka bave terminološkom problematikom; rad Tetyane Fuderer Suvremeno ukrajinsko i hrvatsko sintaktičko nazivlje - poredbeno gledište razotkriva asimetriju u sustavu terminološkoga nazivlja kao rezultat specifičnoga razvoja i potreba odabranih nacionalnih jezika, a Josip Lasić u članku $O$ terminološkim kolebanjima u poljskoj i hrvatskoj hodonomastici otkriva neujednačenost $u$ analiziranim radovima posvećenim hodonomastici te daje vlastiti prijedlog za terminologiju u želji za izjednačavanjem i olakšavanjem budućih istraživanja u području hodonomastike. Pregled je teorijskih razmatranja o razlikama dvaju jezikoslovnih disciplina sa zajedničkim predmetom interesa, izložen u radu Katerine Veljanovske За терминологијата илексикологијата (Oterminologiji ileksikologiji).

Leksikologiji i semantici iz različitih teorijskih pristupa posvećen je najveći broj radova u zborniku. U članku Na sjecištu leksika igramatike: imensko-prijedložne konstrukcije u hrvatskom i ruskom jeziku Daniele Katunar i Ivane Simeon u okviru se konstrukcijske gramatike istražuje produktivnost [N PP] obrasca u funkciji imenovanja na uzorku dobivenom korpusnom analizom s polazišnim hrvatskim jezikom i utvrđuje da je obrazac u odabranom uzorku manje produktivan u ruskom jeziku. U radu Ewe Komorowske Kolorystyka ciała człowieka w ujęciu językowym. Aspekt semantyczno-kognitywny (Koloristika ljudskoga tijela u jezičnoj perspektivi. Semantičko-kognitivni aspekt) kroz kognitivnolingvistički pristup ispitivani su ustaljeni izrazi u poljskom i ruskom jeziku ekscerpirani iz rječnika i govornoga jezika koji opisuju stalne boje kože ili trenutne promjene boje na površini tijela kao 
znak vremenskih, mehaničkih, zdravstvenih i emocionalnih čimbenika. Na slične tvorbene modele koji počivaju na metaforizaciji i metonimizaciji te upotrebu i nijanse u značenju ukazuje rad Pauline Pycia-Košćak Semantička obilježja glagola govorenja u poljskom i hrvatskom kolokvijalnom jeziku. U članku Ide Raffaelli i Ive Borić Similarities and differences of lexicalization patterns in Croatian and Slovene: example of the concept 'touch' (Sličnosti i razlike leksikalizacijskih obrazaca u hrvatskom $i$ slovenskom: primjer pojma 'dodir') otkriveno je analizom rječnika i korpusa da oba jezika imaju iste tipološki relevantne rječotvorne obrasce, [V PP] konstrukcije i prefiksaciju, ali ti modeli leksikaliziraju različita značenja. Lidija Tanuševska u radu Граници на граматикализачијата врз основа на избрани примери од полскиот, македонскиот и хрватскит јазик (Granice gramatikalizacije na temelju izabranih primjera iz poljskoga, makedonskoga i hrvatskoga jezika) prikazuje rezultate kontrastivno proučenih gramatikaliziranih pojava na formalnoj i semantičkoj razini, te zaključuje da su za makedonski jezik u odnosu na ostala dva proučena jezika specifične kategorija određenosti u imenskih riječi, dijatetička transformacija sa sekundarnom tranzitivizacijom, dubitativ te admirativ. U radu Eve Tibenske Emócie i pocity z komparatívneho slovensko-chorvátsko-slovenského hl'adiska, (Emocije i osjećaji iz komparativnoga slovačko-hrvatsko-slovenskoga gledišta) s ciljem da im se dokaže zajedničko slavensko nasljeđe analizirane su rečenične strukture koje pokazuju mikrosituacije 'emocija, osjećaji i njihova očitovanja' te je uočena njihova strukturna podudarnost. Semantičkom analizom, utvrđivanjem mogućnosti prijevoda na izabrane slavenske jezike te analizom višeznačnoga glagola saka bavi se članak Stanislave-Staše Tofoske »Što se 'hoće', šta se 'želi', koga se 'voli' - хрватски и полски еквиваленти на македонскиот глагол 'сака', („Što se 'hoće', šta se '̌̌eli', koga se 'voli'"-hrvatski ipoljski ekvivalenti makedonskoga glagola 'cака').

Sljedeća skupina radova ujedinjena je frazeološkom tematikom; usporedbom strukture, učestalosti, porijekla i značenja frazeoloških jedinica u dvama ili trima jezicima. Podrobna je analiza različitih varijanti frazema crna marica 'policijski automobil', njegova mogućeg porijekla, kulturnoga i simboličkoga potencijala provedena na materijalu hrvatskoga, ruskoga i njemačkoga jezika, a rezultati predstavljeni u članku Branke Barčot i Anite Hrnjak Kada 'crna marica' promijeni boju i ime. U radu Zofije Dembowske Frazelogizmy zawierajace komponent 'czas' w językah: polskim, chorwackim i macedońskim (Frazemi sa sastavnicom 'vrijeme' u poljskom, hrvatskom i makedonskom jeziku) uspoređuje se čestotnost upotrebe izabranih frazeoloških jedinica na temelju rezultata anketiranih ispitanika različite dobi i stupnja obrazovanja te se zaključuje da se u svim trima jezicima frazemi sa sastavnicom 'vrijeme' često koriste i da nema značajne razlika u percepciji vremena među govornicima različitih jezika. Razlika frazeoloških jedinica s izabranom somatskom konstituentom u pogledu strukture i značenja, kao i njihova razdioba prema stupnju ekvivalencije prikazani su u članku Kontrastivna analiza njemačkih, poljskih i hrvatskih frazema sa somatskom sastavnicom 'nos' Petre Koljnrekaj. Odgovoru na pitanje u kojoj mjeru konkretno glazbalo sa svojim stvarnim osobinama utječe na slikovi- 
tost frazema i na koji se način očituju kulturne i povijesne osobitosti na primjeru odabranih frazema sa sastavnicama rog, fanfara, gusle, truba, dipla, lira i kolovrat posvećen je rad Miline Svítkove Problémy interpretácie frazém s polysémantickým komponentom (na príklade slovenských a chorvátdkych jednotiek s komponentami $z$ významovej oblasti hudby) (Problemi interpretiranja fazema višeznačnom sastavnicom (na primjeru slovačkih i hrvatskih frazeoloških jedinica sa sastavnicom iz glazbenog semantičkogpolja).

Na leksikografsku problematiku upućuju tri rada u zborniku. U prvome članku zbornika O leksikografskoj obradi hrvatsko-slovačkih 'lažnih prijatelja' autorica Martina Grčević predstavlja vlastita rješenja primijenjena prilikom izrade rječnika za širi krug korisnika, a to su dvojezičnost i obostrani prijevod, neopširnost, usmjerenost na osnovni i učestali vokabular te preglednost i funkcionalnost. Autorica drugoga rada u zborniku Variability and phraseological patterns from a lexicographic perspective (Varijabilnost i frazeološki obrasci iz leksikografskoga gledišta) predlaže opsežan i sistematičan opis frazema i njihovih varijanti u frazeološkim rječnicima na primjeru bilježenja jednoga frazema i njegovih varijanti u jednojezičnom poljskom i dvojezičnom poljsko-engleskom rječniku. U članku 'Wielki słownik języka polskiego PAN' jako podstawa badań porównawczych nad leksykq̨ słowiańskq ('Veliki rječnik poljskoga jezika Poljske akademije znanosti' kao osnova za poredbena istraživanja slavenskoga leksika) tvorac rječnika Piotr Żmigrodzki daje pregled općih informacija o rječniku, ali iznosi i detalje strukture baze podataka samoga rječnika i naglašava mogućnost korištenja tih baza podataka, uz uvjet postojanje slične baze za neki drugi jezik, kao temelj za poredbena istraživanja.

Članak Branka Tošovića Mrežno generisanje tekstova na slovenskim jezicima prikazuje vrste generatora tekstova, opisuje razliku između prirodno i umjetno generiranih tekstova, ističe da su građa za generatore svi slavenski jezici dostupni u digitalnom obliku te prognozira aktivni daljnji razvoj generatora i približavanje umjetno generiranih tekstova tekstovima na prirodnim jezicima.

Usporedbi morfološke, sintaktičke, stilističke i grafijske funkcije upotrebe velikoga početnog slova u dvama slavenskim jezicima posvećen je rad Eveline Grozdanove O pisanju velikog i malog početnog slova u hrvatskom i bugarskom jeziku u kojem autorica ističe da ne postoji mnogo razlika u uspoređenim normama, ali se u pravopisima nude različiti pristupi rješavanju problema.

Morfološke i sintaktičke teme zastupljene su u sljedećoj cjelini koju čine tri rada. Članak Miroslava Hrdličke i Ivane Vidović Bolt Zašto poljski i hrvatski »glagolski pridjevi radni« nisu ekvivalentni? opisuje razliku u osnovnim obilježjima slične gramatičke pojave; za poljski je jezik tipična atributivna funkcija »glagolskih pridjeva radnih", a za hrvatski tvorba složenih glagolskih oblika, rad također ukazuje na problemi prevođenja i na podudarne ustaljene konstrukcije s analiziranim gramatičkim oblikom. U radu Genitiv u hrvatskom i poljskom jeziku Margareta Katanić analizira sintaksu izabranoga padeža kroz podjelu na besprijedložni genitiv - subjektni, objektni, dijelni i slavenski - i prijedložni, te ističe razliku u upotrebi, prije 
svega, u rekciji glagola, a zatim i brojeva. Jerzy Molas u članku Chorwackie i polskie kontaminacje leksykalne - struktura i funkcije (Hrvatske i poljske stopljenice - struktura i funkcije) prezentira rezultate višerazinske analize poljskih i hrvatskih stopljenica i daje zaključak da su stopljenice u oba jezika nesistematične, okazionalne i ekspresivne naravi te da ne predstavljanju novi rječotvorni model.

Posljednji izdvojeni skup radova tematizira dijalektološke i poredbenopovijesne aspekte slavenske skupine jezika. Članak Mariole Jakubowicz $Z$ badań nad leksyka prasłowiańskq (Iz istraživanja praslavenskoga leksika) donosi prikaz povijesti praslavenske leksikografije, ali i mogućnosti koje otvara digitalizacija rječnike te predlaže etape pri rekonstrukciji praslavenskoga leksika. Rad Polskie i biatruskie gwary grodzieńskie w ujęciu komparatystycznym (Poljski i bjeloruski govori grada Grodna u poredbenoj perspektivi) Katarzyne Konczewske temelji se na usporedbi uzajamnih poljskih i bjeloruskih fonetskih utjecaja na leksik govora u okolici Grodna te pokazuje da se raširenost pojedinoga utjecaju razlikuje u jezičnim uzusima poljskih i bjeloruskih govornika. Autorice Neda Pintarić, Ewa Komorowska, Slavomira Ribarova, Oksana Timko Đitko i Ana Vasung u članku Zajednički korijeni geonima u odabranim slavenskim jezicima i njihova upotreba u frazeologiji i pragmatici provode etimološko-semantičku usporedbu hrvatskih naziva za geološke površine s poljskim, ruskim, staroslavenskim, slovačkim, češkim, ukrajinskim i bugarskim nazivima slavenskih korijena, te pronalaze pragmafrazeme s genonimskom sastavnicom u istraženim jezicima. U radu Refleksi ${ }^{*} d j$, ${ }^{*}$ tj kao prvi divergentni proces u kasnom praslavenskom jeziku autorice Oksana Timko Đitko i Julia Jusyp Jakymovič ukazuju na moguću relativnu kronologiju procesa jotacije $d$ i $t$ i prikazuju raznovrsne i nejednako raspoređene odraze proučavanih suglasničkih skupina te zaključuju da najveća razlika postoji među refleksima u južnoslavenskim jezicima, gdje je jotacija vjerojatno najkasnije počela.

Zbornik Komparativnoslavističke lingvokulturalne teme odlikuje se uistinu velikom tematskom raznolikošću i brojnošću metodoloških pristupa u provedenim istraživanjima, te pridonosi proučavanju bogatstva zajedničkoga jezičnokulturnoga slavenskog nasljeđa. Imajući to vidu, jasno je da može poslužiti kao izvor novih jezičnokulturnih spoznaja o brojnim slavenskim jezicima studentima svih razina filoloških studija, jezikoslovcima i svima koji pokazuju interes za slavenske jezike i kulture. Također, dobro je polazište i za daljnja kontrastivna istraživanja.

Lidija Milković 